\title{
PECULIARITIES OF METABOLIC CHANGES IN ASTHMA
}

10.36740/WLek202010127

\author{
Galyna V. Yeryomenko ${ }^{1}$, Tetiana V. Bezditko ${ }^{1}$, Olena V. Vysotska ${ }^{2}$, Liubov M. Rysovana' ${ }^{1}$, Anna I. Pecherska ${ }^{2}$ \\ 'KHARKIV NATIONAL MEDICAL UNIVERSITY, KHARKIV, UKRAINE \\ 2NATIONAL AEROSPACE UNIVERSITY H.E. ZHUKOVSKY «KHARKIV AVIATION INSTITUTE», KHARKIV, UKRAINE
}

\begin{abstract}
The aim: Revealing of clinical-pathogenetic peculiarities in manifestations of uncontrolled As+MS.

Materials and methods: Sixty-five cases, divided into 2 groups: Group I - severe As ( $n=20)$, Group 2 - severe As+MS ( $n=45)$. The general clinical examination included fasting blood glucose, insulin level, HOMA-IR index, body mass index (BMI), spirometry, levels of MMP-9, MCP-1, IL-8 and IL-12.

Results: In Group I, 20 patients (100\%) had obstructive respiratory dysfunction. Group II had 13 cases (28.88\%) with the restrictive, 15 (33.33\%) with the obstructive and 17 (37.77\%) with the mixed types. BMI revealed: Group I had the normal mass (BMI averaged 24.62 [22.76; 25.71]; Group II had 21 overweighed cases (46.66\%) and 24 (53.33\%) with grade 1 obesity, averaging $29.70[28.35 ; 31.23]$. Correlation analysis in Group II showed significant correlations between: age and WHR $(r=0.52, p<0.001)$ (increase of abdominal fat depots during life), $\mathrm{FEV}_{1}$ and $\mathrm{BMI}(\mathrm{r}=-0.63, \mathrm{p}<0.001)$ (obesity affects pulmonary function). IL-8 and IL-12 levels in Group II were increased, respectively, by 27.86 and 13.18 times versus Group I. A relationship was found between MCP- 1 and MMP-9 $(r=0.77, p<0.05)$, Group II revealed direct correlation between MCP-1 and total FEV $(r=0.53, p<0.05)$. Conclusions: 0 verweight and obesity in As+MS deteriorate respiratory function versus the same indices in isolated As. Relationships between proinflammatory cytokines and MMP-9 and MCP-1 prove pathogenetic peculiarities of systemic inflammation and metabolic homeostasis. As and MS can cause their coexistence, facilitating development of mutual aggravation.
\end{abstract}

KEY WORDS: asthma, metabolic syndrome, interleukins, monocyte chemoattractant, protein 1

Wiad Lek. 2020;73(10):2246-2249

\section{INTRODUCTION}

The problem of comorbidity belongs to the most important ones in internal medicine $[1,2]$. Coexistence of several diseases changes the course of each of them, facilitates an earlier formation of complications and creates difficulties for therapy $[2,3]$. Asthma (As) has significant prevalence all over the world and in Ukraine $[1,4]$. The number of patients with As keeps steadily growing, the number of cases with combination of As and metabolic syndrome (MS) increasing too $[5,6]$. It should be noted that the course and complications of As may be influenced by immunologic changes and some endocrine disorders, such as MS and obesity [5, 7]. The risk of development of MS in patients with As varies from 1.3 to $2.1[8,9]$. The researches, which were conducted for studying an association of As and MS, have demonstrated a close relationship between the functional state of vessels in the lungs and kidneys, a systemic inflammation and metabolic homeostasis $[10,11]$.

MS is often associated with depression of pulmonary function and reduction of forced expiratory volume in one second $\left(\mathrm{FEV}_{1}\right)$ rather than only with abdominal obesity, arterial hypertension and different cardiovascular diseases $[12,13]$. MS, bronchial obstruction and deterioration of pulmonary function can mutually potentiate one another $[14,15]$. A combination of carbohydrate metabolism disorders and As can be caused by both genetic mechanisms, development of an inflammation, formation of energy deficit in tissues and basic therapy for bronchial obstruction syndrome with glucocorticosteroids $[9,14]$.

The development of a persistent inflammation of the respiratory tract in patients with As and the development of smooth muscles hyperplasia depend significantly on the state of the immune system. Side by side with the above, some role in the development and support of an inflammation in the bronchial wall is played by epithelial cells, fibroblasts and vascular endothelial cells. In the process of their activation all these cells secrete a wide range of biologically active substances (leukotrienes, cytokines, chemotactic factors, platelet activating factor, etc.). Disorders in the system of interleukins (IL), roles of matrix metalloproteinase 9 (MMP-9) and monocyte chemoattractant protein 1 (MCP-1) in the process of airway remodelling in combination of As with endocrine pathology are discussed very lively $[16,17]$.

\section{THE AIM}

The aim consisted in revealing clinical-pathogenetic peculiarities in manifestations of As with an uncontrolled course combined with MS. 


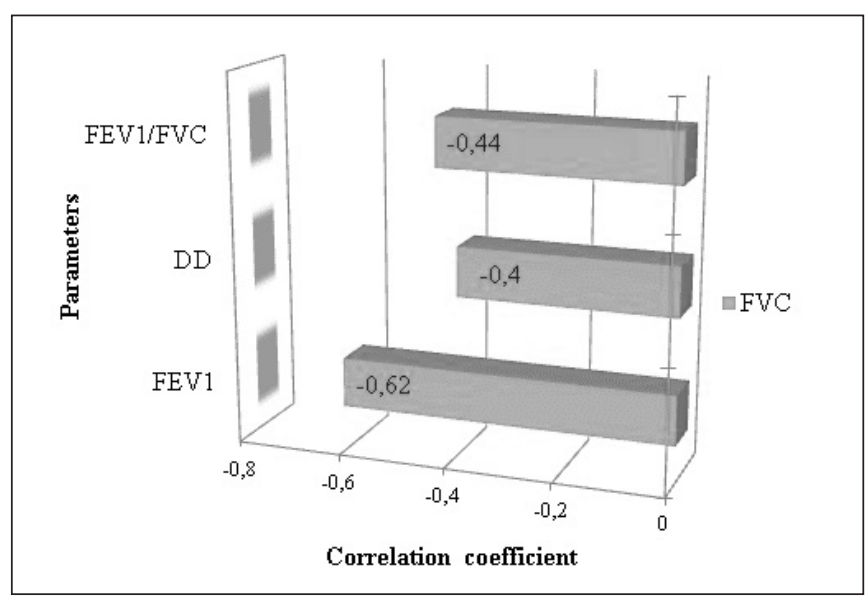

Fig. 1. Correlation dependencies between indices in the group of patients with As+T2DM.

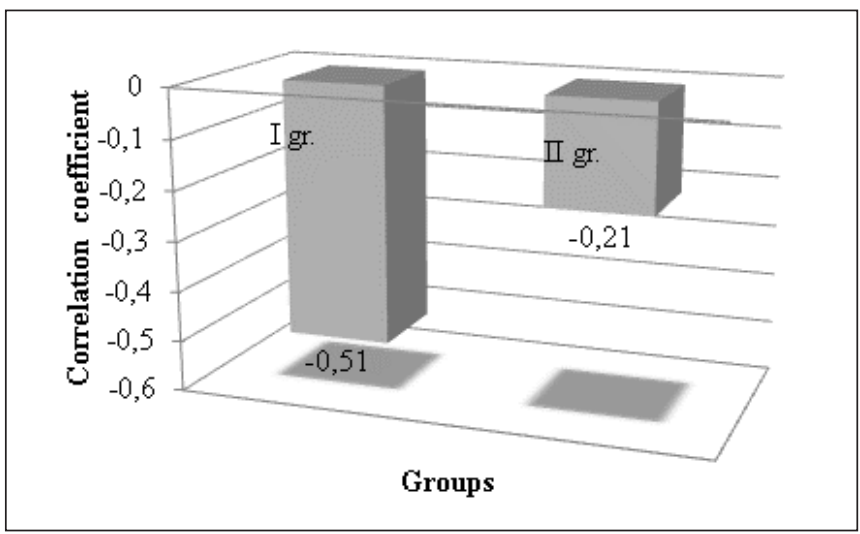

Fig. 2. Correlation dependency between FEV1 index and HbA1c level in both groups.

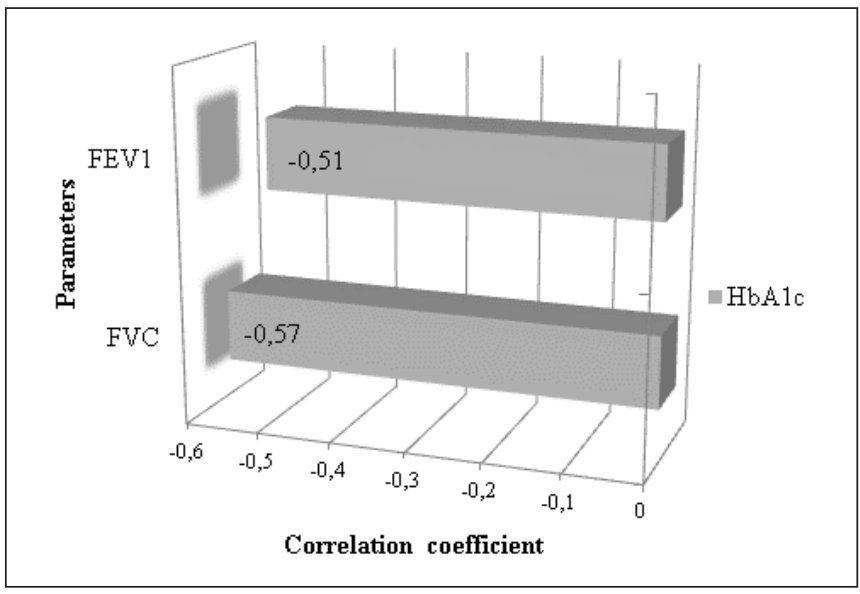

Fig. 3. Correlation dependencies between indices in the group of patients with As+T2DM.

\section{MATERIALS AND METHODS}

Sixty-five patients were examined and divided into 2 groups. Group I included cases with isolated As $(\mathrm{n}=20)$, Group II contained As with MS (As+T2DM) $(\mathrm{n}=45)$. The patients underwent general clinical examination, physical examination, determination of anthropometric data - measurement of weight, calculation of the body mass index (BMI), measurement of the waist and hip circumferences. Respiratory function (RF) was assessed. Fasting blood glucose, insulin level and HOMA-IR index were determined in all cases. The levels of MMP-9 and MCP-1 in blood serum were revealed by ELISA technique with help of "HUMAN MMP-9" and "HUMAN MCP-1" ("eBioscience", Austria) kits. Commercial immunoenzyme test systems "BEST-IFA" ("Vector-Best" Company) were used for quantitation of IL-8 and IL-12.

Findings were statistically processed with help of SPSS 19 program product (IBM, USA). Quantitative changes were described with the following parameters: median (Me), 25th and 75th percentiles ([25\%; 75\%]). In order to reveal differences between independent samples, the Mann-Whitney U test was used. The normality of data distribution was analysed with help of the Shapiro-Wilk test. Correlation analysis with use of the Spearman coefficient (r) and the Chaddock scale was made for assessing relationships between indices.

\section{RESULTS AND DISCUSSION}

In the process of interpretation of different mechanisms in disruption of pulmonary function it was revealed that in 20 patients (100\%) from Group I only the obstructive type of dysfunction was diagnosed. In Group II, there were 13 cases $(28.88 \%)$ with the restrictive type, $15(33.33 \%)$ with the obstructive one and 17 (37.77\%) with the mixed type of a disruption of RF.

Hence, a probable prevalence of the obstructive $(\mathrm{p}<0.001)$ and mixed $(\mathrm{p}<0.001)$ types of ventilation disorders in $\mathrm{pa}-$ tients versus Group I can be caused not only by spasms in smooth muscles of the bronchi, their deformity and expiratory collapse, but also, as some authors believe, by mechanical effects of abdominal obesity in MS resulting from reduced excursion of the diaphragm and chest [18]. According to the results of study of BMI, the patients from Group I had the normal weight: their BMI averaged 24.62 [22.76;25.71]; in Group II, 21 patients (46.66\%) were overweighed and 24 (53.33\%) had grade 1 obesity, averaging 29.70 [28.35; 31.23] in the group. Correlation analysis in patients from Group II revealed marked significant correlations: between age and WHR $(r=0.52, p<0.001)$, demonstrating an increase of abdominal fat depots during life in patients from this group; and between $\mathrm{FEV}_{1}$ and BMI $(\mathrm{r}=-0.63, \mathrm{p}<0.001)$, demonstrating a negative effect of obesity on pulmonary function.

It is known that development of various complications of MS is related to its duration $[10,11]$, therefore we studied a possible appearance of relationships between the duration of MS and development of disorders in RF. A reduction of FVC depending upon the duration of disease and FEV in patients with As+MS (respectively, $\mathrm{r}=-0.40, \mathrm{p}<0.001$ and $\mathrm{r}=-0.62, \mathrm{p}<0.001$ ) according to $\mathrm{FEV}_{1} / \mathrm{FVC}$ index $(\mathrm{r}=-0.44, \mathrm{p}<0.001)$ (Fig. 1). Group I did not demonstrate any statistically significant relationship between $\mathrm{FEV}_{1}$ and duration of disease (Fig.1).

We revealed a statistically significant relationship between the value of $\mathrm{FEV}_{1}$ and the level of HbAlc. The correlation 
Table I. Values of examined indices in patients having As and MS.

\begin{tabular}{|c|c|c|c|c|c|c|c|c|}
\hline \multirow{3}{*}{ Indices } & \multicolumn{3}{|c|}{ As $(n=20)$} & \multicolumn{3}{|c|}{ As+MS $(n=45)$} & \multirow{3}{*}{$\begin{array}{c}\text { Mann-Whiteney } \\
\text { U test }\end{array}$} & \multirow{3}{*}{ Signific-ance, $p$} \\
\hline & \multirow{2}{*}{ Me } & \multicolumn{2}{|c|}{ Percentiles } & \multirow{2}{*}{ Me } & \multicolumn{2}{|c|}{ Percentiles } & & \\
\hline & & $25 \%$ & $75 \%$ & & $25 \%$ & $75 \%$ & & \\
\hline IL-8, pg/ml & 4.61 & 3.80 & 6.90 & 128.42 & 128.36 & 136.65 & 0 & $<0,001$ \\
\hline $\mathrm{IL}-12, \mathrm{pg} / \mathrm{ml}$ & 23.10 & 17.60 & 65.37 & 304.40 & 262.45 & 305.70 & 0 & $<0,001$ \\
\hline MCP-1, ng/ml & 66.51 & 61.00 & 133.71 & 806.14 & 768.36 & 904.37 & 40 & $<0,001$ \\
\hline MMP-9, ng/ml & 42.30 & 38.00 & 72.05 & 786.50 & 386.14 & 933.31 & 95 & $<0,001$ \\
\hline FVC, \% & 98.00 & 97.00 & 99.00 & 66.54 & 54.25 & 73.75 & 217 & $<0,001$ \\
\hline $\mathrm{FEV}_{1}, \%$ & 95.00 & 94.00 & 95.00 & 56.72 & 43.50 & 61.75 & 304 & $<0,001$ \\
\hline $\mathrm{FEV}_{1} / \mathrm{FVC}$ & 82.00 & 81.00 & 83.00 & 70.13 & 62.00 & 78.62 & 458 & $<0,001$ \\
\hline $\mathrm{HbA} 1 \mathrm{c}, \%$ & 5.12 & 4.82 & 5.86 & 7.41 & 7.00 & 7.75 & 7 & $<0,001$ \\
\hline Insulin, mU/I & 19.50 & 17.25 & 20.00 & 17.57 & 14.63 & 20.20 & 1 & $<0,001$ \\
\hline Glucose, $\mathrm{mmol} / \mathrm{l}$ & 4.90 & 4.73 & 5.40 & 8.62 & 7.32 & 10.20 & 9 & $<0,001$ \\
\hline HOMA-IR index & 4.40 & 3.59 & 4.87 & 6.91 & 5.11 & 8.15 & 0 & $<0,001$ \\
\hline BMI & 24.62 & 22.76 & 25.71 & 29.70 & 28.35 & 31.23 & 40 & $<0,001$ \\
\hline
\end{tabular}

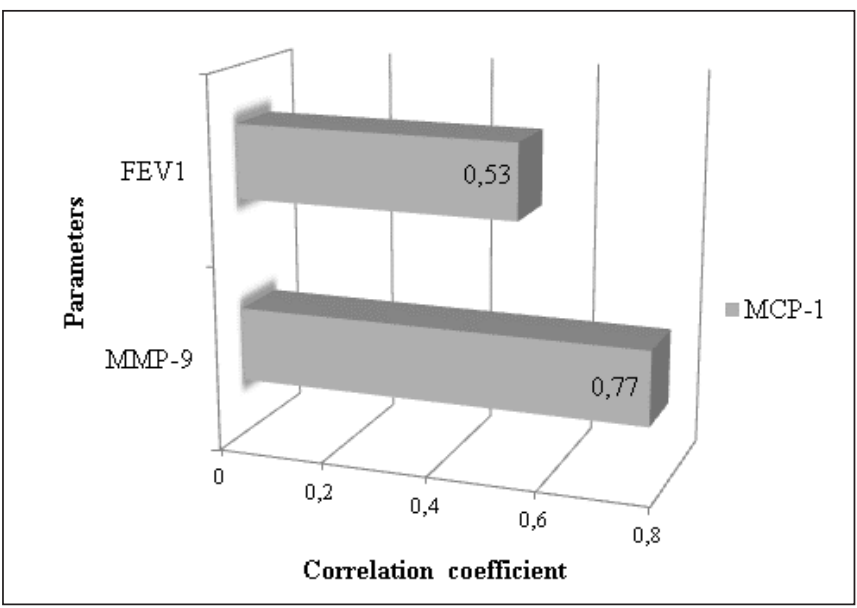

Fig. 4. Correlation dependencies between MCP-1, obstructive syndrome and MMP-9 in patients with As+T2DM.

coefficient was $r=-0.22(p<0.07)$ in Group I and $r=-0.51$ $(\mathrm{p}<0.001)$ in Group II (Fig. 2), the statistically reliable relationship between the value of $\mathrm{FEV}_{1}$ and the level of $\mathrm{HbAlc}$ in patients from Group II being $\mathrm{r}=-0.57, \mathrm{p}<0.05$ (Fig. 3).

The content of IL- 8 and IL- 12 was increased in patients from Group II by, respectively, 27.86 and 13.18 times versus Group I. A high level of proinflammatory cytokines IL-8 and IL-12 $(\mathrm{Me}=128.42 \mathrm{pg} / \mathrm{ml}$ and $304.40 \mathrm{pg} / \mathrm{ml}$, respectively $)$ in an uncontrolled course in patients with As versus T2DM at the stage of exacerbation demonstrates persistence of the chronic inflammatory process that both As and T2DM essentially are (Table I).

Participation of such inflammation markers as MCP- 1 and MMP-9 in the process of inflammation in subjects from this group formed an unfavourable background for progression of the disease and development of bronchial remodeling $[19,20]$. This fact is confirmed by a revealed relationship between MCP- 1 and the mediator of antifibrosis system MMP-9 ( $r=$ $0.77, \mathrm{p}<0.05$ ), which takes part in a cascade of mechanisms with such results as a diffuse chronic inflammation, thickening and hyalinosis of the basal membrane, sclerosis of interalveolar septa [21]. Patients from Group II revealed a direct relationship between MCP- 1 and the total FEV $(r=0.53, \mathrm{p}<0.05)$ (Fig. 4). That is, progression of obstructive syndrome in patients having As+T2DM is associated with a proportional elevation of the fibrotic marker MCP-1.

Our findings show that in patients having As+T2DM an excessive concentration of MCP-1 as the marker of fibrosis during progression of signs of obstructive syndrome is controlled by a proportional growth of the fibrolysis indicator MMP-9, this fact supporting adaptive responses in this category of patients.

\section{CONCLUSIONS}

It was found out that the presence of signs of overweight and obesity in patients with As+MS resulted in deterioration of the state of RF in their lungs versus the same signs in cases with isolated As. Patients with As+MS revealed disruption of their RF in the form of reduced values of FEV/FVC, FEV 1 versus the same indices in cases with isolated As. Relationships were found out between the level of proinflammatory cytokines (Il-8, IL-12) and the levels of MMP-9 and MCP-1.

The view that As+MS are a chronic autoimmune inflammation provides a basis for a more careful study of common components in the pathogenesis of As and MS, which can cause their coexistence and formation of the syndrome of mutual aggravation.

\section{REFERENCES}

1. Feshchenko Yu.I. Asthma and allergies. New Approaches to Improving Bronchial Asthma Treatment in World Practice. 2019; 4: 56-57 (Ua).

2. Feshchenko Yu.I., llinskaya I.F., Aref'eva L.V. et al. Asthma and allergy. Some Approaches to Diagnosis and Prediction of Uncontrolled Bronchial Asthma. 2018; 3: 1-9 (Ua). 
3. GINA 2018; 2018 (cited 2019 Des 27). Available from: https://www. ginasthma.org. [reviewed 2020.02.10]

4. Yashina L.0. Bronchial asthma is an urgent problem today. Ukrainian Pulmonary Journal. 2018; 4: 16-20 (Ua).

5. Dobrorodnia H., Vysotska 0., Gordiyenko N. et al. Studying the mechanisms of formation and development of overweight and obesity for diagnostic information system of obesity. EasternEuropean Journal of Enterprise Technologies. 2016; 6(2): 15-23. doi:10.15587/17294061.2016 .85390

6. Sharma N., Akkoyunlu M., Rabin R.L. Macrophages — common culprit in obesity and asthma. European Journal of Allergy and Clinical Immunology. 2018; 73: 1196-1205. doi: 10.1111/all.13369

7. Mikhailova Yu.A., Kravchun P.G., Petyunina 0.V., Lapshina L.A. The effect of cardioprotection on the state of hemodynamics in the treatment of cardiorenal syndrome in patients with chronic heart failure and chronic kidney disease. International Medical Journal. 2013; 19 (1): 44-49 (Ru).

8. Vandenplas 0., Wiszniewska M., Raulf M. et al. EAACl position paper: irritant-induced asthma. European Journal of Allergy and Clinical Immunology. 2014; 69(9): 1141-53. doi: 10.1111/all.12448

9. Chung K.F., Adcock I.M. Precision medicine for the discovery of treatable mechanisms in severe asthma. European journal of allergy and clinical immunology. 2019; 74: 1649-1659. doi: 10.1111/all.13771

10. Mueller N.T., Koh W.P., Odegaard A.0. et al. Asthma and the risk of type 2 diabetes in the Singapore Chinese Health Study. Diabetes Res Clin Pract. 2013; 99(2): 192-199.

11. Maniscalco M., Fuschillo S., Paris D. et al. Clinical metabolomics of exhaled breath condensate in chronic respiratory diseases. Adv Clin Chem. 2019; 88: 121-149.

12. Mukhin N.A., Moiseev S.V., Fomin V.V. et al. Microalbuminuria is an integral marker of cardiorenal relationships in arterial hypertension. Consilium medicum. 2007; 5: 13-19 (Ru).

13. Pinkhasov B.B., Leutov Yu.V., Karapetyan A.R. et al. Association of age-related obesity with metabolic syndrome in men. The successes of gerantology. 2016; 1: 86-92.

14. Sze E., Bhalla A., Nair P. Mechanisms and therapeutic strategies for non-T2 asthma. European Journal of Allergy and Clinical Immunology. 2019; 01: 1-15. doi: 10.1111/all.13985

15. Yilmaz I., Terl M. Asthma management: A new phenotype-based approach using presence of eosinophilia and allergy. European Journal of Allergy and Clinical Immunology. 2017; 72(9): 1279-1287. doi: 10.1111/ all.13188

16. Te-Chun S., Chia-Wen T., Wen-Shin Ch., et al. Association of Interleukin$12 \mathrm{~A}$ rs568408 with Susceptibility to Asthma in Taiwan. Scientific Reports. 2017; 7: 190-197.

17. Huang H.L., Ho S.Y., Li C.H. et al. Bronchial asthma is associated with increased risk of chronic kidney disease. BMC Pulm Med. 2014; 14: 80.
18. Pankiv V. Treatment Strategies for Obesity. International journal of endocrinology. 2013; 4:12-16.

19. Ventura I., Vega A., Chacón P. et al. Neutrophils from allergic asthmatic patients produce and release metalloproteinase- 9 upon direct exposure to allergens. European Journal of Allergy and Clinical Immunology. 2014; 69: 898-905. doi.org/10.1111/all.12414

20. Jouneau S., Khorasani N., Souza P. Et al. EMMPRIN (CD147) regulation of MMP-9 in bronchial epithelial cells in COPD. Official Journal of the Asian Pacific Society of Respirology. 2011; 16: 705-712. doi.org/10.1111/ j.1440-1843.2011.01960.x

21. Hickman D.A., Syal G., Fausther M. et al. MCP-1 downregulates MMP-9 export via vesicular redistribution to lysosomes in rat portal fibroblasts. Physiological Reports. 2014; 2: 9. doi: 10.14814/phy2.12153.

The work is a fragment of scientific research work of the Department of Propaedeutic of Internal Medicine 2 and Nursing Care Kharkiv National Medical University "Factorsf formation and progression of disorders of external respiration and renal function in conditions of comorbidity of respiratory diseases." (state registration number 0119U002893).

\section{ORCID and contributionship:}

Galyna V. Yeryomenko: 0000-0001-5569-8918 A,B,D,E,F

Tetyana V. Bezditko: 0000-0001-1796-3877 B,D,E,F

Olena V. Vysotska: 0000-0003-3723-9771 ${ }^{\text {A,C }}$

Liubov M. Rysovana: 0000-0001-7937-4176 ${ }^{\mathrm{C}}$

Anna I. Pecherska: 0000-0001-7069-0674 ${ }^{\mathrm{C}}$

\section{Conflict of interest:}

The Authors declare no conflict of interest

\section{CORRESPONDING AUTHOR Galyna V. Yeryomenko \\ Kharkiv National Medical University \\ 4 Nauky Av., 61022 Kharkiv, Ukraine \\ e-mail: galyna0512@ukr.net}

Received: 24.05 .2020

Accepted: 26.08 .2020

A - Work concept and design, B - Data collection and analysis, C - Responsibility for statistical analysis, D-Writing the article, $\mathbf{E}$ - Critical review, $\mathbf{F}$ - Final approval of the article 